\title{
Pendampingan Penulisan Artikel Ilmiah dari Hasil Penelitian bagi Guru Matematika SMK Kota Kediri
}

\author{
Lucky Tri Oktoviana, Dahliatul Hasanah, I Made Sulandra, Susiswo, \\ Trianingsih Eni Lestari, Rini Nurhakiki
}

Departemen Matematika, Fakultas MIPA, Universitas Negeri Malang

Jl. Semarang No.5 Malang 65145

ARTICLE INFO:
Received: 2019-12-27
Revised: 2020-02-03
Accepted: 2020-05-25

Keywords:

Class action research, high school mathematics teacher; scientific article

\section{ABSTRACT}

Doing research and publication in the form of scientific article is not part of teachers' duties as an educator. Conducting research particularly class action research, however, is a necessity for teachers to solve some problems experienced in class. The needs to publish an article from research result emerges from the importance of sharing research result conducting in class. This research result may solve similar problems happened in other classes and experinced by other teachers. High school mathematics teachers in Kediri city encounter difficulties in transforming research result into a scientific article. This community service program provides a training and accompaniment in writing a scientific article. This program involves some activities, i.e. (1) elucidating the structure of scientific articles and its description, (2) giving examples of scientific articles from research results, (3) practicing in writing scientific article, and (4) presenting article results from practice section. This program is expected to encourage high school mathematics teachers in Kediri city to have a scientific article and to publish the article in seminars or scientific journals.

(C) 2020 Published by University of Merdeka Malang. This is an open access article distributed under the CC BY-SA 4.0 license (https://creativecommons.org/licenses/by-sa/4.0/)

How to cite: Oktoviana, L. T., Hasanah, D., Sulandra, I. M., Susiswo, Lestari, T. E., \& Nurhakiki, R. (2020). Pendampingan Penulisan Artikel Ilmiah dari Hasil Penelitian bagi Guru Matematika SMK Kota Kediri. Abdimas: Jurnal Pengabdian Masyarakat Universitas Merdeka Malang, 5(2), 115-122. https://doi.org/10.26905/abdimas.v5i2.3820

\section{PENDAHULUAN}

Berdasarkan Undang-Undang nomor 14 tahun 2005 tentang guru dan dosen, guru adalah pendidik profesional dengan tugas utama mendidik, mengajar, membimbing, mengarahkan, melatih, menilai, dan mengevaluasi peserta didik pada pendidikan anak usia dini jalur pendidikan formal, pendidikan dasar, dan pendidikan menengah. Berbeda dengan dosen, guru tidak mempunyai kewajiban untuk melakukan penelitian. Namun demikian, tidak jarang guru mengalami banyak masalah dan kendala dalam melaksanakan pembelajaran di kelas. Salah satu cara yang dapat ditempuh untuk menyelesaikan masalah dalam 
ABDIMAS: Jurnal Pengabdian Masyarakat Universitas Merdeka Malang

Volume 5, No 2, Juli 2020: 115-122

pembelajaran adalah dengan melaksanakan Penelitian Tindakan Kelas (PTK). Penelitian tindakan kelas merupakan salah satu cara yang strategis bagi pendidik untuk meningkatkan dan atau memperbaiki layanan pendidikan bagi pendidik dalam konteks pembelajaran di kelas (Susilowati, 2018). Dengan melakukan penelitian tindakan kelas, guru mampu memperbaiki proses pembelajaran melalui kajian terhadap apa yang terjadi di kelasnya (Widayati, 2008).

Afandi (2014) menjelaskan dalam artikelnya mengenai pentingnya penelitian tindakan kelas bagi guru. Terdapat tiga hal yang penting dalam PTK, yakni sebagai guru apa yang akan ditingkatkan, metode yang digunakan untuk meningkatkan, serta siapa yang akan ditingkatkan (subyek penelitian). Tidak jarang guru berhasil mengatasi masalah yang dialami di kelas dengan melaksanakan PTK. Pentingnya PTK bagi guru melatarbelakangi Supriyanto (2017) dalam melakukan pelatihan PTK bagi guru sehingga harapannya dengan PTK, kualitas pembelajaran akan meningkat sekaligus prestasi belajar siswa.

Laporan mengenai hasil PTK yang telah dilaksanakan sangat penting untuk dipublikasikan. Hasil PTK yang telah dipublikasi dapat dijadikan referensi bagi guru lain yang menghadapi masalah serupa dalam pembelajaran di kelas. Kebermanfaatan PTK akan bertambah ketika hasil penelitian tersebut dapat dituliskan menjadi artikel ilmiah yang dipresentasikan dalam seminar atau dipublikasikan di jurnal. Namun demikian, banyak guru yang mengalami kesulitan dalam menuliskan artikel ilmiah dari hasil penelitian. Noorjannah (2014) melakukan penelitian di SMA Negeri 1 Kauman Kabupaten Tuluangagung mengenai kesulitan guru dalam menuliskan karya tulis ilmiah. Banyak faktor yang menyebabkan kurangnya publikasi karya tulis ilmiah oleh guru dari hasil penelitian, salah satunya adalah kurangnya pemahaman tentang teknik penulisan artikel ilmiah. Siregar (2011) mengungkapkan bahwa beberapa masalah yang dihadapi guru dalam menuliskan hasil PTK ke dalam artikel ilmiah adalah ketidak mampuan membuat judul, kesulitan menuangkan ide secara efektif, selektifdan berkesinambungan, dan keberanian untuk mencoba.

Dalam menangani kesulitan guru dalam menuliskan artikel ilmiah dari hasil penelitian tindakan kelas, Slameto (2016) menjelaskan lebih rinci mengenai teknik penulisan artikel ilmiah beserta kiat-kiatnya. Kesulitan penulisan artikel ilmiah dari hasil penelitian ini yang menyebabkan beberapa tim pengabdian melakukan pengabdian kepada guru-guru dalam hal penyusunan artikel ilmiah. Mulia \& Suwarno (2016) melakukan pengabdian di SD Negeri Kalisube, Banyumas, dengan tema pengabdian adalah PTK dengan pembelajaran berbasis kearifan lokal dan penulisan artikel ilmiah. Dewi et al. (2017) melakukan pelatihan penulisan artikel ilmiah berbasis penelitian tindakan kelas pada guru SMP Shalahuddin Malang. Pelatihan penulisan karya ilmiah juga dilaksanakan oleh Muhali et al. (2019) bagi guru Madrasah Aliyah Negeri 3 Lombok Tengah. Muhali et al. (2019) mengungkapkan bahwa kesulitan guru adalah salah satunya menuliskan karya ilmiah dari hasil PTK. Dengan serangkaian pelatihan yang dilaksanakan, dilaporkan oleh Muhali et al. (2019) bahwa guru-guru di MAN 3 Lombok Tengah mempunyai potensi untuk mengembangkan diri dalam melaksanakan penelitian dan menghasilkan karya tulis ilmiah.

Kesulitan yang serupa juga ditemui pada guru-guru matematika SMK Kota Kediri. Banyak guru matematika di SMK Kota Kediri sudah melaksanakan PTK namun hasilnya masih belum dipublikasikan dalam seminar atau jurnal. Berdasarkan hasil observasi di MGMP guru matematika SMK Kota Kediri, para guru kesulitan untuk menuliskan hasil penelitian yang dilakukan dalam bentuk artikel ilmiah.

Kegiatan pengabdian kepada masyarakat ini dilakukan oleh beberapa dosen Jurusan Matematika Universitas Negeri Malang berupa pelatihan penulisan artikel ilmiah dari hasil penelitian untuk guru matematika SMK di Kota Kediri. Kegiatan ini merupakan upaya memberikan alternatif solusi dan dorongan semangat bagi guru dalam menyusun artikel ilmiah dengan memberikan materi mengenai bagian apa 


\section{Pendampingan Penulisan Artikel Ilmiah dari Hasil Penelitian bagi Guru Matematika SMK Kota Kediri}

Lucky Tri Oktoviana, Dahliatul Hasanah, I Made Sulandra, Susiswo, Trianingsih Eni Lestari, Rini Nurhakiki

saja yang penting dalam suatu artikel dan bagaimana menuliskannya. Kegiatan pengabdian ini juga dilengkapi dengan pendampingan dalam menyusun artikel ilmiah.

\section{METODE}

Kegiatan ini merupakan kerjasama antara tim pengabdian Jurusan Matematika UM dengan MGMP Matematika SMK Kota Kediri. Kegiatan pengabdian dilaksanakan di SMKN 2 Kediri pada hari Sabtu, 7 September 2019. Lokasi kegiatan ditunjukkan oleh Gambar 1. Kegiatan ini dihadiri oleh 61 guru SMK dan SMA baik negeri maupun swasta. Dalam pelaksanaan kegiatan pengabdian, tim pengabdian UM dibantu oleh 2 mahasiswa dan 2 alumni Jurusan Matematika UM.

Tahapan-tahapan dalam pelaksanaan kegiatan pengabdian kepada masyarakat ini meliputi: (1) Pemberian materi tentang karya ilmiah dan anatomi dari artikel ilmiah, (2) presentasi contoh artikel yang ditulis berdasarkan hasil PTK oleh alumni Jurusan Mtematika UM, dan (3) pendampingan guru-guru peserta dalam praktek penulisan artikel ilmiah dari hasil PTK yang sudah disiapkan masing-masing guru.

Metode penyampaian materi yang digunakan adalah metode ceramah dan diskusi mengenai anatomi artikel ilmiah beserta kiat-kiat khusus dalam menuliskan artikel ilmiah. Setelah itu, peserta diberikan contoh PTK dan artikel ilmiah yang dituliskan berdasarkan PTK tersebut. Contoh ini dipresentasikan oleh guru SMA di Kota Kediri dan merupakan alumni Jurusan Matematika. Setelah itu, kegiatan pengabdian dilanjutkan dengan praktek penulisan artikel ilmiah dari hasil PTK. Gambar 1 menyajikan diagram alur kegiatan PKM ini.

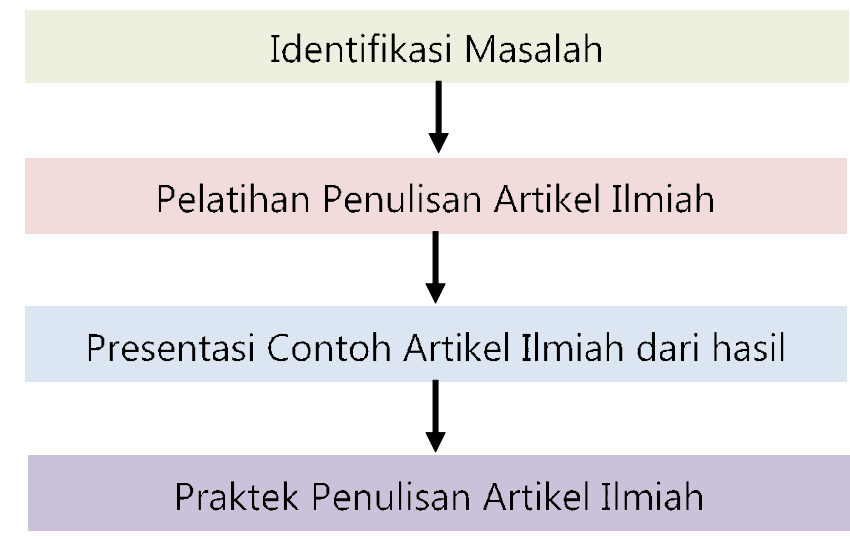

Gambar 1. Diagram Alur Kegiatan PkM

\section{HASIL DAN PEMBAHASAN}

\section{Hasil}

Pelaksanaan kegiatan pelatihan penulisan artikel dari hasil penelitian bagi guru-guru SMK Kota Kediri dilaksanakan di SMKN 2 Kediri. Sasaran kegiatan berjumlah 61 guru-guru matematika SMK dan SMA di Kota Kediri. Pada sesi pertama, para peserta diajak untuk mengamati struktur artikel ilmiah dan mengamati bagian-bagian yang harus dituliskan dalam artikel. Berdasarkan Slameto (2016), artikel ilmiah 
ABDIMAS: Jurnal Pengabdian Masyarakat Universitas Merdeka Malang

Volume 5, No 2, Juli 2020: 115-122

terdiri atas beberapa bagian penting, yaitu: judul artikel, nama penulis, abstrak dan kata kunci, pendahuluan, metode, hasil dan pembahasan, simpulan dan saran, serta daftar rujukan. Salah satu anggota tim pengabdian sebagai narasumber menyajikan materi mengenai artikel ilmiah disajikan oleh Gambar 2.
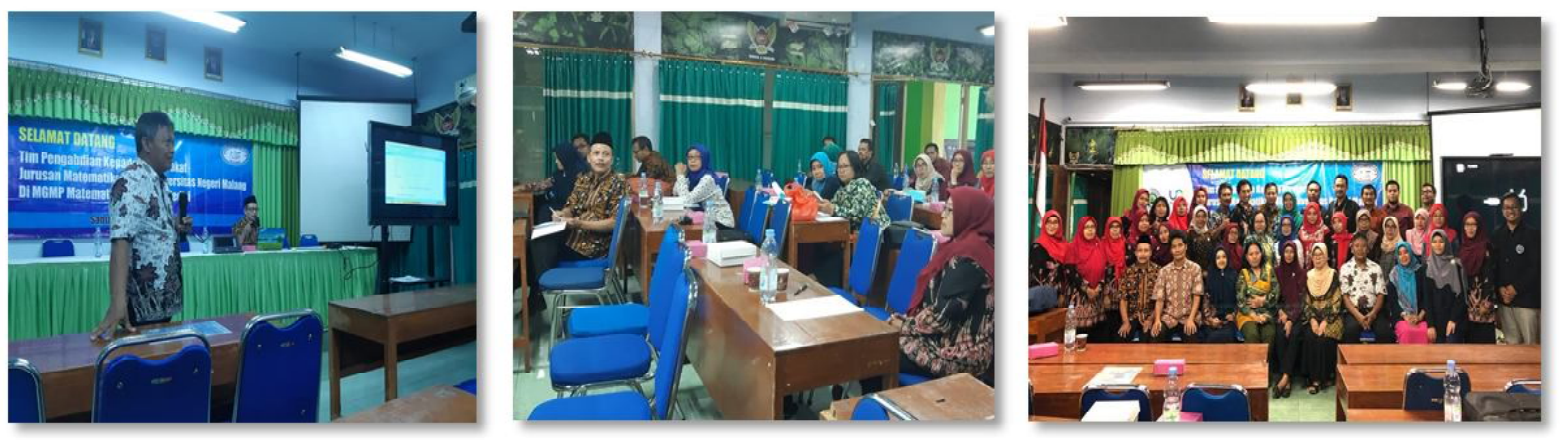

Gambar 2. Penyampaian materi pelatihan oleh Tim Pengabdi Universitas Negeri Malang

Sesi berikutnya, guru-guru diajak mengamati bagian apa saja dari penelitian yang dituliskan dalam karya ilmiah dan bagaimana menuliskannya. Sebagai contoh, tidak semua daftar rujukan yang ada di penelitian dituliskan ulang semuanya di daftar rujukan artikel. Daftar rujukan perlu dipilih mana saja yang digunakan (disitasi) di dalam naskah. Kasus yang sering ditemui adalah adanya sitasi di dalam naskah namun rujukannya tidak dituliskan di dalam daftar rujukan atau sebaliknya, terdapat rujukan dalam daftar namun tidak ditemukan sitasi di dalam naskah artikel.

Setelah materi tentang artikel ilmiah disampaikan oleh tim pengabdian, guru-guru praktek membuat artikel ilmiah dari penelitian yang dimiliki masing-masing. Sebelum pelaksanaan pelatihan dan pendampingan, tim pengabdian meminta guru-guru peserta melalui MGMP untuk menyiapkan hasil penelitian masing-masing yang telah dilaksanakan. Hasil penelitian ini sebagai calon yang akan dituliskan kembali dalam bentuk artikel ilmiah.

Pada sesi 1 dan 2, tim pengabdian juga memberikan contoh artikel yang disusun berdasarkan hasil penelitian. Hal ini sangat diperlukan untuk memberikan gambaran kepada peserta apa saja yang perlu dimunculkan dalam suatu artikel ilmiah dan bagaimana menuliskannya. Tahap selanjutnya adalah praktek menulis artikel dari hasil penelitian. Pada sesi ini, guru-guru diminta untuk menyusun artikel, yaitu paling sedikit menyusun judul, abstrak, dan pendahuluan yang tepat. Peserta pelatihan menulis ulang ke artikel ilmiah dengan semangat dan kerja keras dengan banyak diskusi dengan teman sejawat maupun menanyakan hal-hal yang kurang dipahami kepada narasumber.

Setelah menyusun artikel dari hasil penelitian masing-masing, beberapa peserta mempresentasikan hasil artikel yang disusun untuk mendapatkan saran dari narasumber maupun dari peserta lainnya. Gambar 3 menunjukkan salah satu peserta mempresentasikan hasil artikel yang telah disusun selama sesi praktek penulisan. Pada sesi ini, peserta antusias untuk memperhatikan dan memberikan tanggapan atas hasil pekerjaan teman sejawat. Selanjutnya, peserta diminta untuk menyelesaikan artikel ilmiah masing-masing sebagai tugas individu yang harus dikirimkan kepada tim pengabdian melalui email. Tugas ini untuk melihat keefektifan kegiatan pengabdian dan untuk melihat perkembangan kemampuan peserta dalam menulis artikel ilmiah. 

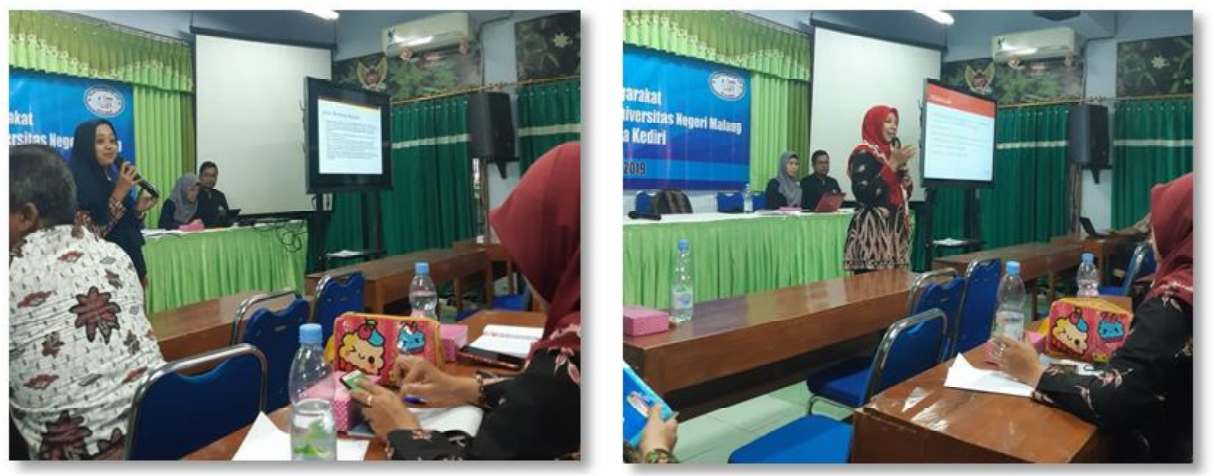

Gambar 3. Salah satu peserta mempresentasikan hasil artikel ilmiah yang disusun

\section{Pembahasan}

Karena keterbatasan waktu kegiatan pengabdian kepada masyarakat, praktek penyusunan artikel ilmiah difokuskan untuk menyusun judul, latar belakang dan rumusan masalah yang sesuai. Sebagian peserta mampu menyusun judul artikel yang sesuai dengan latar belakang dan isi penelitian. Namun juga ada beberapa judul artikel yang kurang sesuai dengan latar belakang yang disusun oleh guru. Berikut merupakan beberapa contoh judul artikel yang disusun oleh peserta pelatihan: (1) Penerapan Model Pembelajaran Student Fasilitator and Explaining untuk meningkatkan kemampuan berpikir kritis matematika Siswa Kelas X Busana 1 SMK Negeri 3 Kediri tahun pelajaran 2019-2020. (2) Penerapan Pendekatan Matematika Realistik untuk meningkatkan kemampuan Siswa XI BKP1 dalam membuat model matematika pada materi program linear. (3) Penerapan Model CTL Berbasis Kejuruan untuk meningkatkan kemampuan penalaran siswa pada Materi Sistem Persamaan Linear dengan Dua Variabel di Kelas X APK 1 SMK Pawyatan Daha 1 Kediri. (4) Efektifitas Metode Contextual Model Problem Posing dalam upaya meningkatkan hasil belajar Matematika Pokok Bahasan Matriks pada Siswa Kelas XI AKL 1 SMK Negeri 2 Kediri. (5) Penerapan metode pembelajaran kooperatif Model Team Assisted Individualization untuk meningkatkan prestasi belajar Statistika pada Siswa Kelas XII TKI SMKN 1 Kediri tahun 2019/2020. (6) Upaya meningkatkan pembelajaran Sistem Persamaan Linear Tiga Variabel lewat metode belajar aktif Model Memberikan Pertanyaan dan Mendapatkan Jawaban pada Siswa Kelas X semester gasal SMK Negeri 1 Kediri tahun pelajaran 2019-2020.

Dari beberapa judul kemudian dibahas mengenai beberapa contoh kesesuaian dan ketidaksesuaian dalam menyusun artikel ilmiah. Artikel dengan judul "Penerapan Metode Pembelajaran Kooperatif Model Team Assisted Individualization untuk meningkatkan prestasi belajar statistika pada Siswa Kelas XII TKI SMKN 1 Kediri tahun 2019/2020" memuat beberapa kata kunci, yakni "Metode Pembelajaran Kooperatif Model Team Assisted Individualization", "Prestasi Belajar", dan "Statistika". Dengan kata-kata kunci tersebut, latar belakang yang diberikan seharusnya membahas mengapa metode tersebut yang digunakan dan mengapa materi statistika yang dipilih. Namun demikian, penulis tidak memberikan keterangan apapun mengenai ketiga kata kunci dalam latar belakangnya. Ini menunjukkan ketidaksesuaian antara judul yang dipilih dengan latar belakang yang diberikan.

Ketidaksesuaian antara judul dan latar belakang juga ditemukan pada artikel dengan judul "Upaya meningkatkan pembelajaran Sistem Persamaan Linear Tiga Variabel lewat metode belajar aktif Model 
ABDIMAS: Jurnal Pengabdian Masyarakat Universitas Merdeka Malang

Volume 5, No 2, Juli 2020: 115-122

Memberikan Pertanyaan dan Mendapatkan Jawaban pada Siswa Kelas X Semester Gasal SMK Negeri 1 Kediri tahun pelajaran 2019-2020". Penulis tidak membahas sama sekali mengenai "Model Memberikan Pertanyaan dan Mendapatkan Jawaban" dalam pendahuluannya, sehingga keterangan tentang model tersebut dan alasan pemilihannya tidak diketahui. Berdasarkan judul tersebut, kata peningkatan harus merupakan suatu hasil yang bisa dibandingkan dengan hasil sebelumnya agar bisa dikatakan sebagai peningkatan, namun dalam judul tersebut yang akan ditingkatkan adalah pembelajarannya yang tentu tidak dapat dibandingkan dengan pembelajaran sebelumnya tanpa parameter yang jelas.

Di sisi lain, artikel dengan judul "Peningkatan prestasi belajar matematika Materi Komposisi dan Invers Fungsi dengan pembelajaran kooperatif Tipe Teams Game Tournament (TGT) pada siswa Kelas X OTKP-1 SMK Negeri 2 Kediri tahun pelajaran 2019-2020" memberikan latar belakang yang sesuai dengan judul tersebut. Penulis membahas mengapa memilih model tipe TGT dibandingkan dengan pembelajaran kooperatif tipe yang lain. Penulis juga memberikan alasan yang tepat mengapa memilih materi komposisi dan invers fungsi sebagai bahan penelitian. Namun banyak kata dalam judul tersebut disarankan untuk dikurangi sehingga menjadi judul yang efektif.

Berdasarkan artikel-artikel yang dikumpulkan oleh peserta, beberapa peserta menyusun judul artikel yang sesuai dengan latar belakang, namun beberapa yang lain masih kesulitan untuk menyusun judul dan latar belakang yang sesuai. Keefektifan dari pelatihan dianggap masih rendah. Hal ini disebabkan karena waktu pelatihan yang sangat singkat sehingga banyak guru yang masih merasa kesulitan dalam menyusun artikel dari penelitan tindakan kelas yang dimiliki. Dengan demikian, pelatihan lanjutan mengenai penyusunan artikel masih sangat dibutuhkan oleh guru.

Sasaran kegiatan pengabdian kepada masyarakat ini adalah guru-guru matematika SMK dan SMA di Kota Kediri. Kegiatan ini dihadiri oleh 61 orang guru matematika. Kewajiban utama guru adalah mendidik dan mengajar dan tidak ada kewajiban utama untuk meneliti maupun mempublikasikan hasil penelitian melalui artikel ilmiah. Namun demikian, melakukan peelitian di kelas maupun publikasi ke seminar atau jurnal menjadi suatu kebutuhan bagi guru. Sebelum kegiatan pengabdian tentang penulisan hasil penelitian menjadi artikel ilmiah, banyak guru yang masih kebingungan menuliskan hasil penelitiannya (seringkali berupa PTK) untuk menjadi artikel ilmiah. Tidak jarang yang dilakukan guru adalah menuliskan semua yang ada di hasil ke penelitian ke artikel ilmiah sehingga jumlah halaman artikel menjadi sangat banyak. Tidak jarang juga latar belakang yang diberikan tidak menggambarkan masalahdan alternatif solusi yang ditawarkan. Dengan berbagai kondisi tersebut, guru-guru khususnya di Kota Kediri menginginkan pendampingan yang berkelanjutan sehingga semakin banyak guru yang mampu mempublikasikan hasil penelitiannya dalam seminar atau jurnal ilmiah.

Setelah mengikuti pelatihan dan pendampingan penulisan artikel ilmiah oleh tim pengabdian Jurusan Matematika Universitas Negeri Malang, guru-guru matematika SMK dan SMA Kota Kediri merasa lebih percaya diri dalam menuliskan artikel ilmiah. Keberanian dalam menuliskan artikel ilmiah ini dimulai dari menuliskan judul yang tepat dan efektif kemudian dilanjutkan dengan menuliskan latar belakang yang sesuai dengan kondisi dan tujuan yang ingin dicapai. Dengan permulaan yang bagus ini diharapkan para guru peserta pendampingan mampu mempublikasikan hasil penelitiannya dalam seminar atau jurnal ilmiah. 


\section{Pendampingan Penulisan Artikel Ilmiah dari Hasil Penelitian bagi Guru Matematika SMK Kota Kediri}

Lucky Tri Oktoviana, Dahliatul Hasanah, I Made Sulandra, Susiswo, Trianingsih Eni Lestari, Rini Nurhakiki

\section{SIMPULAN DAN SARAN}

\section{Simpulan}

Kegiatan pengabdian kepada masyarakat yang melibatkan guru matematika SMK dan SMA Kota Kediri telah berjalan dengan baik sesuai dengan yang direncanakan. Kegiatan ini diharapkan sebagai alternatif solusi dalam mengatasi kegelisahan para guru SMK Kota Kediri dan sebagai dorongan semangat untuk mempublikasikan hasil penelitiannya ke dalam seminar atau jurnal. Melalui pelatihan ini, guru belajar untuk menuliskan ulang laporan PTK yang dimiliki dalam bentuk karya ilmiah yang siap diterbitkan dalam prosiding atau jurnal ilmiah. Pelatihan ini fokus pada penulisan judul dan latar belakang dari artikel ilmiah. Hasil dari pelatihan didapatkan bahwa masih ada guru yang kesulitan menuliskan judul yang efektif dan menuliskan latar belakang yang sesuai. Namun demikian, sebagian besar guru SMK dan SMA Kota Kediri peserta pelatihan mampu menuliskan ulang laporan PTK menjadi artikel ilmiah yang baik.

\section{Saran}

Kegiatan pengabdian kepada masyarakat ini dilaksanakan dalam satu hari. Hal ini menyebabkan materi yang disampaikan terbatas dan waktu yang digunakan dalam praktek menulis artikel ilmiah juga terbatas. Antusiasme peserta pelatihan dan pendampingan sangat bagus. Agar mendapatkan hasil yang lebih maksimal, sebaiknya perlu diadakan pendampingan lebih lanjut sehingga peserta mampu mendapatkan artikel ilmiah jadi sebagai luaran akhir dari kegiatan pengabdian.

\section{UCAPAN TERIMA KASIH}

Tim Penulis mengucapkan terima kasih kepada PNBP UM yang telah memberi dukungan moral dan dana terhadap program pengabdian masyarakat ini. Ucapan terima kasih juga disampaikan kepada MPMP Matematika SMK Kota Kediri atas kerjasama yang baik.

\section{DAFTAR PUSTAKA}

Afandi, M. (2014). Pentingnya penelitian tindakan kelas bagi guru dalam pembelajaran di sekolah dasar. Jurnal IImiah Pendidikan Dasar, 1(1), 1-19. http://dx.doi.org/10.30659/pendas.1.1.1-19

Dewi, P. K. Rizal, M. S., Ardhian, D. \& Hardinata, V. (2017). Pelatihan penulisan artikel ilmiah Berbasis Penelitian Tindakan Kelas pada guru SMP. Jurnal ABDI: Media Pengabdian Kepada Masyarakat, 2(2). http://dx.doi.org/10.26740/ja.v2n2.p7-17

Muhali, Asy'ari, M., Prayogi, S., Samsuri, T., Karmana, I. W., Sukarma, I. K., Mirawati, B., Firdaus, L., \& Hunaepi. (2019). Pelatihan kegiatan penelitian dan penulisan karya ilmiah bagi guru Madrasah Aliyah Negeri 3 Lombok Tegah. ABDIHAZ: Jurnal IImiah Pengabdian pada Masyarakat, 1(1), 2836. https://doi.org/10.32663/abdihaz.v1i1.739.

Mulia, D. S., \& Suwarno. (2016). PTK (Penelitian Tindakan Kelas) dengan Pembelajaran Berbasis Kearifan Lokal dan penulisan artikel ilmiah di SD Negeri Kalisube Banyumas. Khazanah Pendidikan: Jurnal Ilmiah Kependidikani, IX(2).

Noorjannah, Lilies. 2014. Pengembangan profesionalisme guru melalui penulisan karya tulis ilmiah bagi guru profesional di SMA Negeri 1 Kauman Kabupaten Tulungagung. Jurnal Humanity, 10(1), 97-114. 


\section{ABDIMAS: Jurnal Pengabdian Masyarakat Universitas Merdeka Malang}

Volume 5, No 2, Juli 2020: 115-122

Siregar, I.F. 2011. Pelatihan pengembangan laporan hasil penelitian indakan kelas menjadi artikel imiah untuj jurnal bagi guru-guru Sekolah Dasar Kota Semarang dalam upaya meningkatkan kompetensi profesional. ABDIMAS, 15(2), 121-130.

Slameto. 2016. Penulisan artikel ilmiah hasil penelitian tindakan kelas. Scholaria, 6(2), 46-57. https://doi.org/10.24246/j.scholaria.2016.v6.i2.p46-57

Supriyanto, A. (2017). Peningkatan kemampuan guru dalam penulisan karya ilmiah melalui pelatihan penelitian tindakan kelas. Abdimas Pedagogi, 1(1), 1 - 7.

Susilowati, D. (2018). Penelitian Tindakan Kelas (PTK) solusi alternatif problematika pembelajaran. Jurnal IImiah Edunomika, 2(1), 36 - 46.

Widayati, A. (2008). Penelitian Tindakan Kelas. Jurnal Pendidikan Akuntansi Indonesia, 6(1), 87-93 